\title{
Precision of doctor's diagnoses of cancers, pre-cancer conditions atypical and dysplastic lesions
}

\author{
Ewa Ziajka', Jan Błaszczyk ${ }^{2}$
}

${ }^{1}$ Individual Medical Practice, Haffnera str 12c, 81-717 Sopot, Poland, ${ }^{2}$ Head of Departament of Human Physiology, Medical University of Lodz, Plac Hallera 1, Lodz, Poland

Corresponding author: Dr. Ewa Ziajka, E-mail: ewaziajka@wp.pl

\begin{abstract}
Background: The prevalence of skin cancers increases, therefore it is necessary to use effective screening tools that allow for quick, efficient and reliable diagnosis of the disease. The aim of the study is to determine the level of precision of selected diseases by comparing the diagnoses made by doctors with the results of histopathological examination. Material and Methods: The study included 709 patients' disease histories whose skin lesions were first subjected to clinical evaluation, followed by removal and verification of the clinical evaluation by means of histopathological examination. The analysis was carried out with reference to cancers, pre-cancer conditions, dysplastic and atypical lesions jointly named labelled as "group" and separately for cancers. To assess precision of clinical diagnosis sensitivity, specificity, LR and chi2 and Kappa test were used. Results: On the basis of the clinical evaluation fewer changes from the "group" were identified than were finally discovered in the histopathological evaluation (99 vs. 128). The results of the chi2 test $(\mathrm{p}=0.0000)$ indicated that the frequency of recognizing the "group" conditions was statistically significantly different in doctors' and histopathological assessment. The value of the Kappa statistics (0.62) indicated a satisfactory level of compliance. The sensitivity was $60.63 \%$, but a high specificity was achieved (96.96\%). In the assessment of the cancers alone, better coherence parameters were obtained - Kappa 0.76, sensitivity $70.45 \%$ and specificity $99.27 \%$. The LR + indicator was as high as 96.95, which means that the diagnosis is reliable. Conclusion: Diagnostic precision can be considered satisfactory, especially in the case of neoplastic changes. However, attention should be paid to the parameters that show some deficiencies, especially low sensitivity.
\end{abstract}

Key words: Dermoscopy; Nevus; Precision of dermoscopy

How to cite this article: Ziajka E, Błaszczyk J. Precision of doctor’s diagnoses of cancers, pre-cancer conditions atypical and dysplastic lesions. Our Dermatol Online. 2018;9(e):e3.1-e3.6.

Submission: 20.05.2018; Acceptance: 07.08.2018

DOI: 10.7241 /ourd.2018e.2 


\title{
Precyzja diagnozy klinicznej chorób nowotworowych, stanów przedrakowych oraz zmian o cechach atypii i dysplazji
}

\section{Ewa Ziajka ${ }^{1}$, Jan Błaszczyk ${ }^{2}$}

${ }^{1}$ Individual Medical Practice, Haffnera str 12c, 81-717 Sopot, Poland, ${ }^{2}$ Head of Departament of Human Physiology, Medical University of Lodz, Plac Hallera 1, Lodz, Poland

Corresponding author: Dr. Ewa Ziajka, E-mail: ewaziajka@wp.pl

\begin{abstract}
RESUME
Wstęp: Częstość występowania nowotworów skóry wzrasta, dlatego konieczne jest stosowanie skutecznych narzędzi do badań przesiewowych, które pozwolą na szybkie, skuteczne i wiarygodne diagnozowanie choroby. Celem badania jest określenie poziomu precyzji klinicznej diagnozy wybranych chorób poprzez porównanie diagnozy stawianej przez lekarzy z wynikami badań histopatologicznych. Material i Metody: Badaniem objęto 709 historii chorób pacjentów, których zmiany skórne najpierw zostały poddane ocenie klinicznej, a następnie usunięte i zweryfikowane przy pomocy badania histopatologicznego. Analizę przeprowadzono w odniesieniu do raków, stanów przedrakowych, dysplastycznych i o cechach atypii, łącznie nazwanych jako "grupa" i osobno dla nowotworów (raków). Do oceny precyzji klinicznej czułości diagnostycznej i swoistości użyto testy wairygodności LR i test chi2 (chi-kwadrat) oraz statystyki Kappa. Wyniki: Na podstawie oceny klinicznej zidentyfikowano mniej zmian z "grupy" w porównaniu z liczbą, która ostatecznie została wykazana w badaniu histopatologicznym (99 vs 128). Wyniki testu chi2 $(p=0,0000)$ pokazały, że częstość rozpoznawania zmian z "grupy" wykazywała statystycznie istotne różnice między oceną lekarza i badaniem histopatologicznym. Wartość statystyki Kappa $(0,62)$ osiągnęła satysfakcjonujący poziom zgodności. Czułość diagnostyczna wyniosła $60,63 \%$, ale uzyskano wysoką swoistość $(96,96 \%)$. Przy ocenie samych raków uzyskano lepsze parametry koherencji - Kappa 0,76, czułość 70,45 \% i swoistość 99,27\%. Wskaźnik LR + wyniósł aż 96,95, co oznacza, że diagnoza jest wiarygodna. Wnioski: Precyzję diagnostyczną można uznać za zadowalającą, zwłaszcza w przypadku zmian nowotworowych (neoplastycznych). Należy jednak zwrócić uwagę na parametry wykazujące pewne niedostatki, w szczególności niższą czułość.
\end{abstract}

Słowa klucze: Dermoskopia; Znamię; Precyzja dermoskopii

\section{WSTĘP}

Częstość rozpoznawania raków skóry rośnie. Szacuje się, że od kilkunastu lat co roku rozpoznawane jest o około 10-15\% raków skóry więcej, w tym czerniaków skóry [1]. Zachorowalność na czerniaka jest zróżnicowana globalnie i waha się w przedziale 4-50 zachorowań na 100.000 mieszkańców. W Polsce roczna liczba zachorowań na czerniaka wśród mężczyzn to 1200, a wśród kobiet 1350 przypadków [2]. Najczęściej rozpoznawanym rodzajem raka skóry jest rak podstawnokomórkowy (ang. ang. Basal Cell Carcinoma - BCC), stanowiący około 65-75\% rozpoznań oraz rak kolczystokomórkowy (ang. Squamous Cell Carcinoma - SCC) stanowiący 20-30\% rozpoznań $[3,4]$. Duże rozpowszechnienie i umieralność uzasadniają poszukiwanie i wdrażanie skutecznych narzędzi skiningowych, pozwalających na szybkie, sprawne i pewne rozpoznanie choroby.

Celem badania jest określenie poziomu precyzji klinicznej diagnozy chorób skóry poprzez porównanie diagnoz stawianych przez lekarzy z wynikami badania

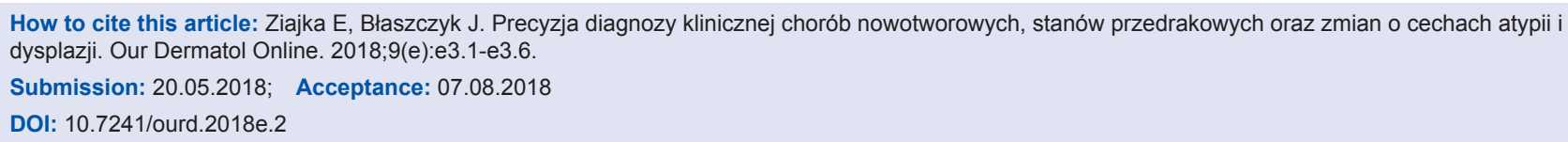


histopatologicznego. Poza zmianami nowotworowymi istotna z punktu widzenia rokowania jest diagnoza dokonana na etapie zmiany przedrakowej, dysplastycznej lub o cechach atypii, gdyż wówczas szanse na pełen wyleczenie są największe [5].

\section{MATERIA I METODY}

Do badania włączono 709 historii choroby pacjentów leczonych w Specjalistycznej Przychodni Lekarskiej dla Pracowników Wojskowych, którzy w latach 2008-2011 mieli wykonany zabieg usunięcia zmiany skórnej. Włączono historie tych chorych, u których zmiany skórne w pierwszej kolejności poddano ocenie klinicznej, następnie dokonano ich usunięcia i weryfikacji oceny klinicznej przy pomocy badania histopatologicznego.

Analizę przeprowadzono w odniesieniu do zmian charakteryzujących się największym zagrożeniem dla pacjentów tj. raków, stanów przedrakowych, dysplastycznych i o cechach atypii, łącznie nazywanych jako „grupa” oraz osobno dla raków. W celu dokonania oceny precyzji posłużono się wskaźnikami czułości, swoistości oraz wiarygodności LR (ang. likehood ratio). Poziom zgodności oszacowano za pomocą testu chi2 i statystyki Kappa, a następnie zinterpretowano zgodnie z dostępnymi schematami.

\section{WYNIKI}

Średni wiek w grupie badanej wyniósł 49 lat. Większą część, bo $60,5 \%$ grupy badanej stanowiły kobiety $(n=429)$, mężczyźni stanowili odpowiednio 31,5\% $(n=280)$.

\section{OCENA KLINICZNA - „GRUPA”}

W ocenie klinicznej lekarze wyróżnili 38 rodzajów zmian. Najczęściej rozpoznawanym było znamię barwnikowe, które rozpoznano w 287 przypadkach (39,15\% ogółu), znamię komórkowe ( $\mathrm{n}=118 ; 16,10 \%)$ i włókniak twardy $(n=50 ; 6,83 \%)$. Klinicyści rozpoznali 98 zmian o charakterze nowotworowym, przedrakowym, określonych jako atypowe lub dysplastyczne, co stanowiło 13,23\% ogółu. W grupie tej najczęściej rozpoznawano raka podstawnokomórkowego $(n=35)$ (Tabela 1).
Tabela 1: Rodzaje rozpoznań nowotworowych, stanów przedrakowych, dysplastycznych i o cechach atypii na podstawie oceny klinicznej

\begin{tabular}{lccc}
\hline Rodzaj rozpoznania (, grupa") & N & $\begin{array}{c}\text { \% ogółu } \\
\text { rozpoznań }\end{array}$ & \% w grupie \\
\hline Rak podstawnokomórkowy & 35 & 4,78 & 35,71 \\
Rogowacenie słoneczne & 22 & 3,01 & 22,45 \\
Znamię barwnikowe a typowe & 21 & 2,87 & 21,43 \\
Róg skórny & 13 & 1,78 & 13,27 \\
Rogowiak kolczystokomórkowy & 2 & 0,27 & 2,04 \\
Plama soczewicowata & 1 & 0,14 & 1,02 \\
Rak kolczystokomórkowy & 1 & 0,14 & 1,02 \\
Znamię komórkowe a typowe & 1 & 0,14 & 1,02 \\
Choroba Bowena & 1 & 0,14 & 1,02 \\
Leukoplakia & 1 & 0,14 & 1,02 \\
SUMA & 98 & 13,39 & 100,00 \\
\hline
\end{tabular}

OCENA HISTOPATOLOGICZNA - „GRUPA”

W badaniu histopatologicznym z kolei rozpoznano większą liczbę rodzajów zmian $(\mathrm{N}=73)$. Najczęściej rozpoznawano znamię barwnikowe $(n=236 ; 32,20 \%$ ogółu rozpoznań,) znamię komórkowe $(n=51 ; 6,96 \%)$ oraz raka podstawnokomórkowego $(n=41 ; 5,59 \%)$.

W ocenie histopatologicznej rozpoznano 128 przypadków znamion o charakterze nowotworowym, przedrakowym, atypowych lub dysplastycznych. Znamiona te stanowiły 17,49\% ogółu zmian poddanych ocenie histopatologicznej (Tabela 2).

\section{PORÓWNANIE ROZPOZNAŃ - OCENA PRECYZJI DLA ,GRUPY”}

$\mathrm{Na}$ podstawie oceny klinicznej rozpoznano mniej zmian z "grupy" niż finalnie dokonano tego w ocenie histopatologicznej (99 vs. 128). Wyniki testu chi2 wskazały, że częstość rozpoznawania zmian z omawianej grupy w ogóle rozpoznań była statystycznie istotnie różna pomiędzy diagnozami postawionymi przez lekarzy i w badaniu histopatologicznym (chi2 = $288,4225 ; \mathrm{p}=0,0000)$.

Wartość statystyki Kappa oszacowano na poziomie 0,62, co sugeruje zadowalającą zgodność diagnoz. Porównując poszczególne diagnozy stwierdzono, że lekarze osiągnęli czułość diagnostyczną na poziomie 60,63\%, wykazali się jednak większą swoistością (96,63\%), co oznacza, że taki odsetek osób zdrowych w rzeczywistości w taki właśnie sposób sklasyfikowali. Wynik LR+ o wartości 16,67 wskazuje, że uzyskanie pozytywnego wyniku w ocenie klinicznej wiąże się 
Tabela 2: Rodzaje rozpoznań nowotworowych, stanów przedrakowych, dysplastycznych i o cechach atypii na podstawie oceny histopatologicznej

\begin{tabular}{|c|c|c|c|}
\hline Rodzaj rozpoznania (, grupa") & $\mathbf{N}$ & \% w ogóle & $\%$ w grupie \\
\hline Rak podstawnokomórkowy & 41 & 5,60 & 32,03 \\
\hline Plama soczewicowata & 24 & 3,28 & 18,75 \\
\hline Rogowacenie słoneczne & 21 & 2,87 & 16,41 \\
\hline Róg skórny & 8 & 1,09 & 6,25 \\
\hline Rogowiak kolczystokomórkowy & 5 & 0,68 & 3,91 \\
\hline Znamie barwnikowe a typowe & 5 & 0,68 & 3,91 \\
\hline Znamię barwnikowe dysplastyczne brzeżne & 4 & 0,55 & 3,13 \\
\hline Znamie dysplastyczne brodawkowate barwnikowe skóry & 3 & 0,41 & 2,34 \\
\hline Znamię dysplastyczne częściowo soczewicowatebarwnikowe skóry & 3 & 0,41 & 2,34 \\
\hline Znamie soczewicowate łączące skóry & 3 & 0,41 & 2,34 \\
\hline Czerniak & 2 & 0,27 & 1,56 \\
\hline Plama soczewicowata barwnikowa & 2 & 0,27 & 1,56 \\
\hline Znamię a typowe dysplastyczne częściowo soczewicowate barwnikowe skóry & 2 & 0,27 & 1,56 \\
\hline Choroba Bowena & 1 & 0,14 & 0,78 \\
\hline Leukoplakia & 1 & 0,14 & 0,78 \\
\hline Rak kolczystokomórkowy & 1 & 0,14 & 0,78 \\
\hline Złosliwy włóknisty mięsak histiocytarny & 1 & 0,14 & 0,78 \\
\hline Znamię dysplastyczne częściowo soczewicowate brodawkowate barwnikowe skóry & 1 & 0,14 & 0,78 \\
\hline SUMA & 128 & 17,49 & 100,00 \\
\hline
\end{tabular}

Tabela 3: Wyniki testu Kappa, czułości i swoistości oraz wskaźnika LR dla porównania diagnozy klinicznej i histopatologicznej - dla tzw. grupy zmian

\begin{tabular}{lc}
\hline Cecha & Wartość \\
\hline Observet agreement & 0,900 \\
Expected agreement & 0,737 \\
Kappa statistic & 0,620 \\
$95 \% \mathrm{Cl}$ & $0,54-0,70$ \\
$\mathrm{SE}$ & 0,040 \\
$\mathrm{SE}$ & 0,037 \\
Z statistic & 16,98 \\
2 - tailed p & $<0.0001$ \\
Czułość & $60.63 \%(95 \% \mathrm{Cl}-51,57 \%-69.18 \%)$ \\
Swoistość & $96.36 \%(95 \% \mathrm{Cl}-94.55 \%-97.71 \%)$ \\
Wskaźnik wiarygodności dla testu & $16.67(95 \% \mathrm{Cl}-10.81-25.72)$ \\
dodatniego LR+ & \\
Wskaźnik wiarygodności dla testu & $0.41 \%(95 \% \mathrm{Cl}-33-0.51)$ \\
ujemnego LR- & \\
\hline
\end{tabular}

z dużym prawdopodobieństwem tego, iż zmiana faktycznie jest z grupy raków, stanów przedrakowych, dysplastycznych lub o cechach atypii (Tabela 3).

\section{PORÓWNANIE ROZPOZNAŃ - OCENA PRECYZJI DLA RAKÓW SKÓRY}

Lekarze rozpoznali również mniej przypadków raków skóry niż finalnie zdiagnozowano w badaniu histopatologicznym (36 vs. 44). Wyniki testu chi2 wskazały istnienie statystycznie istotnych różnic w częstości rozpoznawania tych stanów (chi2 $=428,98$; $\mathrm{p}=0,0000)$.

W przypadku diagnostyki raków skóry wyniku testu Kappa $(0,76)$ wskazał na dobrą zgodność wyników w
Tabela 4: Wyniki testu Kappa, czułości i swoistości oraz wskaźnika LR dla porównania diagnozy klinicznej i histopatologicznej - dla tzw. raków

\begin{tabular}{lc}
\hline Cecha & Wartość \\
\hline Observet agreement & 0.975 \\
Expected agreement & 0.897 \\
Kappa statistic & 0.76 \\
$95 \% \mathrm{Cl}$ & $0.66-0.87$ \\
$\mathrm{SE}$ & 0.054 \\
$\mathrm{SE}$ & 0.037 \\
$Z$ statistic & 20.74 \\
2 tailed $P$ & $<0.0001$ \\
Czułość & $70.45 \%(95 \% \mathrm{Cl}-54.80 \%-83.24 \%)$ \\
Swoistość & $99.27 \%(95 \% \mathrm{Cl}-98.31 \%-99.76 \%)$ \\
Wskaźnik wiarygodności dla testu & $96.95(95 \% \mathrm{Cl}-39.65-237.04)$ \\
dodatniego LR+ & \\
Wskaźnik wiarygodności dla testu & $0.30(95 \%-0.19-0.47)$ \\
ujemnego LR- &
\end{tabular}

grupach. Wyniki oceny czułości i swoistości wskazują, że klinicyści zdiagnozowali prawidłowo 70,45\% osób z rakami. Lekarze wykazali się bardzo dobrą swoistością na poziomie 99,27\%, co oznacza, że taki odsetek osób zdrowych w rzeczywistości w taki sposób zostało zdiagnozowanych. Wartość wskaźnika wiarygodności LR + na poziomie 96,95 wskazuje, że uzyskanie pozytywnego wyniku w ocenie klinicznej wiąże się z dużym prawdopodobieństwem tego iż zmiana faktycznie jest z grupy raków (Tabela 4).

\section{DYSKUSJA}

Rak skóry należy do najczęściej rozpoznawanych rodzajów choroby nowotworowej na świecie. Najbardziej niebezpieczny rodzaj raka skóry - czerniak jest 
rozpoznawany 3,6 razy częściej dziś niż w latach 70tych XX wieku [6,7].

Zasady rozpoznawania rodzaju zmian skórnych na podstawie oceny klinicznej, głównie z wykorzystaniem dermoskopii, znane są od dziesiątków lat jednakże dyskusja światowa w zakresie zwiększania efektywności tej metody i jej uniwersalizacji nie może być uznana za zakończoną [8-10]. Ocena kliniczna dokonana przez sprawnego diagnostę wciąż pozostaje ważnym i najłatwiej dostępnym rodzajem badania wykonywanym w diagnostyce raka skóry, nie jest jednak uznawana za idealne badanie skriningowe ze względu na niewystarczające parametry precyzji [11]. Warto jednak zauważyć fakt, że badaniu w Lore i wsp. wykazano, że jednorazowe badanie TBE (ang. Total Body Examination) polegające na ocenie klinicznej wszystkich zmian znajdujących się na skórze jest najbardziej efektywną kosztowo metodą zapobiegania przedwczesnym zgonom z powodu raka skóry, zwłaszcza u kobiet [12].

W niniejszym badaniu oznaczono wskaźniki precyzji w odniesieniu do wszystkich rozpoznań z grupy raków, stanów przedrakowych, dysplastycznych i o cechach atypii (oznaczonych w pracy jako „grupa”) i odrębnie dla samych raków. Ogólna czułość dla "grupy” wyniosła 60,63\%, a dla raków 70,45\%. W innych badaniach klinicyści również uzyskiwali podobne wyniki czułości i swoistości - dla zmian niemelanocytowych $50,5 \%$ a dla czerniaków lepsze aczkolwiek wciąż niskie - 22,2\% [13]. Inni autorzy również wskazują na tożsame problemy związane z brakiem idealnej zgodności dermoskopii [14,15].

Na uwagę zasługuje wartość statystyki Kappa wyznaczonej dla zgodności oceny klinicznej i histopatologicznej. Zgodnie z ogólnymi kryteriami oceny poziomu zgodności wyniki te należy uznać za zadowalające [16]. W badaniach innych autorów wartość statystyki Kappa wahała się. Przykładowo w opracowaniu Ojeda i wsp. wyniosła ona 0,56 [17], czyli wartość z przedziału średniego dopasowania. W badaniu Riegel i wsp. zbadano z jaką czułością i swoistością lekarze zlecają wykonanie biopsji w przypadku niewielkich czerniaków. Okazało się, że poziom zgodności można było uznać jedynie za zadowalający, bo wartość statystyki Kappa wyniosła 0,31 dla samego rozpoznania i 0,34 dla celowości biopsji [18]. Należy zwrócić uwagę na fakt, iż statystyka Kappa należy do rzadziej wykorzystywanych przez badaczy narzędzi, którzy częściej wykorzystują w ocenie zgodności takie parametry jak czułość czy swoistość.
Według najnowszych danych Światowej Organizacji Zdrowia WHO (ang. World Health Organization) na świecie rocznie na raka niemelanocytowego choruje 2-3 milionów osób, a na czerniaka 132.000 osób przyczyniając się do wielu zgonów. Zgodnie ze statystykami, Polska należy do krajów z wysokimi wskaźnikami umieralności, zajmując aktualnie 18 lokatę wśród krajów świata jeśli chodzi o wskaźnik umieralności z powodu raka skóry [19]. Oznacza to, że Polska należy do państw, które najpilniej potrzebują skutecznych rozwiązań pozwalających na poprawę sytuacji epidemiologicznej.

\section{WNIOSKI}

Precyzja diagnostyczna lekarzy może być uznana za zadowalającą, szczególnie w przypadku zmian nowotworowych. Należy jednak zwrócić uwagę na parametry świadczące o pewnych niedostatkach w precyzji diagnostyki dokonanej przez lekarzy, zwłaszcza na niższą niż w innych krajach czułość.

\section{Statement of Human and Animal Rights}

All procedures followed were in accordance with the ethical standards of the responsible committee on human experimentation (institutional and national) and with the Helsinki Declaration of 1975, as revised in 2008 .

\section{Statement of Informed Consent}

Informed consent was obtained from all patients for being included in the study.

\section{REFERENCES}

1. American Cancer Society. Survival rates for melanoma skin cancer by stage. Available from: http://www.cancer.org/cancer/ skincancer-melanoma/detailedguide/melanoma-skin-cancersurvival-rates-by-stage20/09/2016

2. Krajowy Rejestr Nowotworów. Czerniak skóry (C43). Available from: http://onkologia.org.pl/czerniak-skory-c43/\#r

3. Genç I, Çakmak S, Tamer E, Güreşçi S, Ünal D. A case of breast carcinoma presenting as carcinoma en cuirasse. Our Dermatol Online. 2018;9:154-6.

4. Diabate A, Kourouma H, Vagamon B, Gué I, Kaloga M, Aka B. Skin pathology of the elderly patients: Case of black African. Our Dermatol Online. 2018;9:19-21.

5. Placek W, Markiewicz A, Zając N, Bzdawski M. Rogowacenie słoneczne - definicja, etiopatogeneza i możliwości terapeutyczne. Przegl Dermatol. 2013;100:171-7.

6. Sonnappa U, Samayam A. Our Dermatol Online. 2018;9:160-3.

7. Al-Kamel M. Keratoacanthoma of the nose coexisted with xeroderma pigmentosum in a Yemeni child: A rare case. Our Dermatol Online. 2016;7:419-21. 


\section{www.odermatol.com}

8. Malakar S, Mehta P, Mukherjee S, Malakar S. Dermoscopic surprises in a series of 6 cases. Our Dermatol Online. 2018;9:51-6.

9. Malakar S, Mukherjee S. Dermoscopy unveils the mystery of a deceptive nodule. Our Dermatol Online. 2017;8:495-6.

10. Malakar S, Mukherjee S, Malakar S. Uniform faint reticulate pigment network - A dermoscopic hallmark of nevus depigmentosus. Our Dermatol Online. 2018;9:225-6.

11. US Preventive Services Task Force et al. Screening for Skin CancerUS Preventive Services Task Force Recommendation Statement. JAMA. 2016;316:429-35.

12. Lore P, Hoorens I, Vossaert K, Kruse V, Tromme I, Speybroeck N, et al. Cost-effectiveness and Budget Effect Analysis of a PopulationBased Skin Cancer Screening. JAMA Dermatol.2017;153:147-53.

13. Koelink C, Vermeulen K, Kollen B, de Bock G, Dekker J, Jonkman M, et al. Diagnostic accuracy and cost-effectiveness of dermoscopy in primary care: a cluster randomized clinical trial. JEADV. 2013;28:1442-9.

14. Arif T, Amin S, Adil M. Facial porokeratosis - Rare presentation of an uncommon disease.: Our Dermatol Online. 2016;7:353-4.

15. Raveendra L. A clinical study of geriatric dermatoses. Our Dermatol Online. 2014;5:235-9.

16. Diering M, Dyczkowski K, Hamrol A. Szacowanie poziomu zgodności ocen w kontroli wizualnej-problemy w wyznaczaniu współczynników typu kappa. [w: ] Innowacje w zarządzaniu i inżynierii produkcji. Knosal R. (red). Wyd. Oficyna Wydawnicza Polskiego Towarzystwa Zarządzania Produkcją, 2015.

17. Ojeda R, Graells J. Effectiveness of Primary Care Physicians and Dermatologists in the Diagnosis of Skin Cancer: a Comparative Study in the Same Geographic Area. Actas Dermo-Sifilograficas (English Edition). 2011;102:48-52.

18. Riegel D, Russack J, Friedman R. Ewolucja w diagnostyce czerniaka złośliwego: 25 lat po wprowadzeniu kryteriów ABCD. Onkol Dypl. 2011;8:49-68.

19. Programme World Health Ranking. Skin Cancer Mortality Rates. Available from: http://www.worldlifeexpectancy.com/cause-ofdeath/skin-cancers/by-country/11-02-2017.

Copyright by Ewa Ziajka, et al. This is an open access article distributed under the terms of the Creative Commons Attribution License, which permits unrestricted use, distribution, and reproduction in any medium, provided the original author and source are credited.

Source of Support: Nil, Conflict of Interest: None declared. 